\title{
RODZINNE UWARUNKOWANIA POSTAW ŻYWIENIOWYCH STUDENTÓW OPARTYCH NA RELIGIJNOŚCI
}

\section{FAMILY DETERMINANTS AND STUDENTS' RELIGIOUS DIETARY CUSTOMS}

\author{
Agnieszka Buczak ${ }^{1(\mathrm{~A}, \mathrm{~B}, \mathrm{C}, \mathrm{D}, \mathrm{E}, \mathrm{F}, \mathrm{G})}$
}

${ }^{1}$ Wydział Pedagogiki i Psychologii, Uniwersytet Marii Curie-Skłodowskiej w Lublinie

Buczak, A. (2017). Rodzinne uwarunkowania postaw żywieniowych studentów opartych na religijności. Rozprawy Społeczne, 11(4), 28-35. https://doi.org/10.29316/rs.2017.35

Wkład autorów:

A. Zaplanowanie badań

B. Zebranie danych

C. Dane - analiza i statystyki

D. Interpretacja danych

E. Przygotowanie artykułu

F. Wyszukiwanie i analiza

literatury

G. Zebranie funduszy

\begin{abstract}
Streszczenie
Wstęp. Celem pracy jest analiza postaw żywieniowych związanych z praktykowaniem religijności w kontekście uwarunkowań rodzinnych. Podjęte badania stanowią przykład empirycznego zastosowania bliskiej edukacji zdrowotnej koncepcji postaw, których źródłem jest przyjęty światopogląd.

Materiał i metody. Badania sondażowe przeprowadzono w 2016 roku w trzech ośrodkach akademickich. Wzięło w nich udział 387 studentów kierunków nauczycielskich. Postawy żywieniowe oparte na religijności diagnozowano przy użyciu autorskiej Skali Postaw Żywieniowych, zweryfikowanej poprzez analizę czynnikową i dyskryminacyjną. Do badania uwarunkowań rodzinnych posłużyły Skale Oceny Rodziny A. Margasińskiego.

Wyniki. Zależności między oceną funkcjonowania rodziny a postawami żywieniowymi opartymi na religijności są modyfikowane przez płeć jako zmienną pośredniczącą. W grupie badanych mężczyzn pozytywna ocena funkcjonowania rodziny sprzyja przestrzeganiu zasad religijnych związanych ze sposobem odżywiania. W przypadku kobiet zależności nie są tak znaczące i raczej mają charakter ujemny.

Wnioski. Religijność stanowi czynnik różnicujący postawy żywieniowe związane ze światopoglądem. Istotne znaczenie dla kształtowania postaw żywieniowych opartych na religijności mają relacje w rodzinie pochodzenia.
\end{abstract}

Słowa kluczowe: postawy żywieniowe, religijność, uwarunkowania rodzinne, studenci

\section{Summary}

Introduction. The study aims to analyse religious dietary customs determining family life. The research is an example of an empirical application of the concept of attitudes whose origins lie in one's adopted worldview, which is also true of health-promoting education.

Material and methods. The survey was conducted in 2016 in three academic centres. It involved 387 students studying in teacher training courses. Nutritional customs based on one's religiosity were diagnosed using a proprietary Nutritional Attitude Scale, verified by factorial and discriminatory analysis. In the investigation of family-related determinants, the Family Assessment Scales by A. Margasiński were used.

Results. The relationship between the assessment of the family functioning and nutritional dietary customs related to religiousness are influenced by gender, which acts as an intermediary variable. It turns out that, in the group of the surveyed men, a positive assessment of family's functioning is conducive to the observance of religious principles related to nutritional customs. In the case of women, the dependencies are not so significant as there are fewer correlations.

Conclusions. Religiousness differentiates nutritional customs of people with different worldviews. The family background and internal relationships are important factors determining religious nutritional and dietary customs.

Ryciny: 0

Literatura: 47

Otrzymano: czerwiec 2017

Zaakceptowano: sierpień 2017

\section{Wstęp}

Postawy żywieniowe stanowią interdyscyplinarny obszar zainteresowań badawczych, analizowany głównie z punktu widzenia zdrowia. W psychologii często są postrzegane w kategoriach klinicznych, w literaturze zagranicznej opisywane jako disordered eating attitudes (Morris, Parra, Stender, 2011). W promocji zdrowia oraz naukach o żywieniu i żywności preferencje wybory i postawy wobec odżywiania są wyrazem troski o zdrowie (Czarnocińska, Jeżewska-Zychowicz, Babicz-Zielińska, Kowalkowska, 
Wądołowska, 2013; Maison, 2013, Babicz-Zielińska, Zabrocki, 2007). Coraz częściej postawy żywieniowe stają się przedmiotem zainteresowania socjologii, antropologii kulturowej, pedagogiki (Fox, 2003).

W pracy posłużono się definicją postaw żywieniowych L. Narojek, która uznaje je jako „ogólne jednoczesne ustosunkowanie się do różnych problemów składających się na całość żywienia jednostki lub rodziny" (Narojek, 1993, s. 50). Postawy żywieniowe zgodnie psychologiczną koncepcją postaw posiadają komponent poznawczy, emocjonalny i behawioralny, które „nie są zupełnie rozłączne i pozostają we wzajemnych zależnościach" (Jeżewska-Zychowicz, 2007 , s. 152). Do analizy postaw związanych z odżywianiem wykorzystywany jest soczewkowy model postaw proponowany przez B. Wojciszke (2002). Składnik poznawczy, emocjonalny i behawioralny raczej biorą udział w kształtowaniu postaw, wyjaśniają ich genezę oraz konsekwencje, niż opisują same postawy żywieniowe (Jeżewska-Zychowicz, 2007).

Wśród uwarunkowań postaw żywieniowych najczęściej wymieniane są czynniki biologiczne, głównie oparte na funkcjonowaniu ośrodków głodu i sytości w podwzgórzu (Gawęcki, 2010; Konturek, 2013) oraz psychospołeczne, w tym osobowościowe (Ogińska-Bulik, Juczyński, 2008),związane z samooceną (Ziółkowska, 2014) i samoskutecznością (Nastaskin, Fiocco, 2015), wpływem społecznym rodziny (Collins, Duncanson, Burrows, 2014), rówieśników (Houldcroft, Haycraft, Farrow, 2014), mediów (Kozirok, 2015). Uwarunkowania rodzinne najczęściej badane są w kontekście kształtowania postaw w procesie wychowania (Holubcikova, Kolarcik, Madarasova Geckova A, van Dijk, Reijneveld, 2016). Postawy żywieniowe nabywane są nie tylko przez modelowanie postaw rodzicielskich. Duże znaczenie mogą mieć dobre relacje wewnątrzrodzinne, a także wspólne posiłki (Fulkerson, Neumark-Sztainer, Story, 2006; Tabak, 2015; Stalmach, 2015).

Edukacja zdrowotna zmierza do zmiany zachowań zdrowotnych poprzez oddziaływanie na system wartości, przekonań i postaw jednostki (Whitehead, 2004). Związek postaw i zachowań zdrowotnych z wyznawanym światopoglądem (zwłaszcza chrześcijańskim) podkreślany jest również w pedagogice zdrowia przez M. Demela (2002). Konsekwencją przyjęcia światopoglądu jest posiadanie postaw wobec różnych obiektów, osadzonych w wyznawanej ideologii. Ze względu na społeczną rolę ideologii, wyrażającą się m.in. w integracji i kontroli społecznej (Borowiec, Lingowska, 2012), w przypadku postaw żywieniowych obiektem może być własny sposób odżywiania, ale także sposób odżywiania się innych.

Przykładem postaw żywieniowych, których źródłem jest światopogląd są postawy oparte na religijności związane z etyką umiaru i przestrzeganiem postu polegającego na okresowym powstrzymywaniu się od niektórych produktów żywnościowych. Posty stanowią element życia duchowego wszystkich wielkich religii świata. Wyrzeczenie, ascetyzm, abstynencja, oczyszczenie ciała przez post i unikanie niektórych pokarmów stanowią częste praktyki religijne (Baxter, 2001). Religia katolicka, którą według różnych statystyk wyznaje 80-90\% Polaków wyznacza zasady związane z przyjmowaniem pokarmów: szacunek do jedzenia - zwłaszcza chleba, który traktowany jest jako pokarm uświęcony (Zwoliński, 2006, Buczak, 2017), etyka umiaru odnosząca się do unikaniu nadmiernego jedzenia (Zwoliński, 2008), okresowy post, którego celem jest zbliżenie do Boga, pokuta za grzechy i powtórne wejście na drogę do świętości, unikanie niektórych pokarmów - głównie produktów mięsnych, będące wyrazem ćwiczenia woli (Leszczyński, 2014).

Celem podjętych badań było ustalenie zależności między oceną funkcjonowania rodziny studentów kierunków nauczycielskich a postawami żywieniowymi, których źródłem jest światopogląd religijny. Postawy żywieniowe oparte na religijności były w Polsce analizowane raczej epizodycznie (np. Kucharska, Sińska, Marszałek, Michota-Katulska, Zegan, 2015, Woźniak, 2013. Badania prowadzone w tym zakresie w Stanach Zjednoczonych czy krajach arabskich (np. Hossain, 2014; Kim, 2007; Smith, Richards, Maglio, 2004) trudno porównać ze względu na różnice kulturowe. Relacje w rodzinie pochodzenia to przykład uwarunkowań rodzinnych postaw żywieniowych rzadko analizowanych w literaturze w porównaniu do czynników związanych z modelowaniem postaw i zachowań żywieniowych przez członków rodziny. Ponadto rodzinne uwarunkowania przedstawiane są jako korelaty postaw żywieniowych raczej związanych ze zdrowiem, niż np. praktykami religijnymi (Rawlings, 2009; Steeves, Jones-Smith J, Hopkins, Gittelsohn, 2016). Opisywane badania stanowią zatem uzasadnioną perspektywę badawczą.

\section{Materiał i metody}

Badania sondażowe przeprowadzono w czerwcu oraz październiku 2016 roku w trzech ośrodkach akademickich: Lublinie, Białej Podlaskiej oraz Rzeszowie. Wzięło w nich udział 387 studentów kierunków nauczycielskich. Średnia wieku respondentów to $21,5(\mathrm{SD}=2,22)$. Wśród badanych studentów było 271 kobiet - 70\% i 116 mężczyzn - 30\%.

Prezentowane wyniki badań stanowią fragment rezultatów szerszego projektu badawczego autorki „Wybrane korelaty typów postaw żywieniowych przyszłych nauczycieli" ${ }^{1}$. Dane na temat postaw żywieniowych studentów kierunków nauczycielskich (w tym postaw religijnych) zostały pozyskane przy użyciu autorskiej Skali Postaw Żywieniowych, zweryfikowanej analizą czynnikową i dyskryminacyjną.

\footnotetext{
Artykuł przygotowany w ramach projektu finansowanego ze środków z dotacji celowej na prowadzenie badań naukowych lub prac rozwojowych służących rozwojowi pracowników naukowodydaktycznych Wydziału Pedagogiki i Psychologii UMCS. Zadanie badawcze: Edukacja wobec problemów współczesności; Projekt badawczy: Wybrane korelaty typów postaw żywieniowych przyszłych nauczycieli BS-P-07-006-16-1-06.
} 
Twierdzenia budujące podskale narzędzia badawczego odnosiły się zarówno trzech komponentów postawy: poznawczego (np. „Przestrzeganie nakazów związanych $\mathrm{z}$ jedzeniem jest dla mnie jednym z ważniejszych elementów religijności”), emocjonalnego (np. „Akceptuję religijne zasady związane z jedzeniem”) i behawioralnego (np. „Podczas postu unikam jedzenia mięsa"). Ponadto odrębne podskale miały za zadanie diagnozować stosunek do własnego sposobu odżywiania (postawy „wewnętrzne)” oraz stosunek do sposobu odżywiania innych (postawy „zewnętrzne”). W rezultacie analizy czynnikowej wyodrębniono jako jedną $\mathrm{z}$ pięciu postaw wobec własnego sposobu odżywiania postawę religijną wewnętrzną oraz jako jedną z pięciu postaw wobec odżywiania się innych - postawę religijną zewnętrzną.

Rodzinne uwarunkowania postaw żywieniowych zostały zbadane przy pomocy narzędzia Skale Oceny Rodziny Andrzeja Margasińskiego, które stanowi polską adaptację FACES IV - Flexibility and Cohesion
Evaluation Scales Davida H. Olsona (Olson, 2013, Margasiński, 2006). Podstawowe zmienne opisujące życie rodzinne w tym modelu to Spójność i Elastyczność, które moga przyjmować trzy poziomy nasilenia. Najbardziej korzystne dla funkcjonowania rodziny są wysokie wyniki uzyskiwane w skalach Zrównoważona Spójność i Zrównoważona Elastyczność. Niezwiązanie, Splątanie, Sztywność i Chaotyczność świadczą o niezdrowych relacjach w rodzinie. Poza spójnością i elastycznością oceniana jest również komunikacja i zadowolenie z życia rodzinnego (Margasiński, 2013).

\section{Wyniki}

Wyniki średnie uzyskane w podskalach opisujących postawy żywieniowe oparte na religijności (postawy religijne wewnętrzne i zewnętrzne) porównano ze względu na płeć badanych w tabeli 1.

Tabela 1. Różnice w religijnych postawach żywieniowych związane z płcią badanych studentów - test U Manna - Whitneya

\begin{tabular}{|l|c|c|c|c|c|c|c|c|}
\hline \multirow{2}{*}{ Postawy żywieniowa } & \multicolumn{2}{|c|}{$\begin{array}{c}\text { Kobieta } \\
\text { N=271 }\end{array}$} & \multicolumn{2}{c|}{$\begin{array}{c}\text { Mężczyzna } \\
\text { N=116 }\end{array}$} & \multicolumn{2}{c|}{$\begin{array}{c}\text { Ogółem N=387 } \\
\text { Nest U Manna - } \\
\text { Whitneya }\end{array}$} \\
\cline { 2 - 10 } & $\mathrm{M}$ & $\mathrm{SD}$ & $\mathrm{M}$ & $\mathrm{SD}$ & $\mathrm{M}$ & $\mathrm{SD}$ & $\mathbf{Z}$ & p \\
\hline Religijna wewnętrzna & 29,82 & 11,83 & 26,86 & 11,38 & 28,94 & 11,76 & 2,319 & $\mathbf{0 , 0 2 0}$ \\
\hline Religijna zewnętrzna & 27,21 & 10,42 & 26,33 & 9,75 & 26,94 & 10,22 & 0,677 & 0,498 \\
\hline
\end{tabular}

${ }^{*} \mathrm{p}<0,05$

Źródło: badanie własne.

Analiza danych zawartych w tabeli 1 pozwala zauważyć istotne statystycznie różnice $\mathrm{w}$ postawach religijnych studentów kierunków nauczycielskich wobec własnego sposobu odżywiania (typ postawy religijny wewnętrzny). Płeć nie różnicuje jednak postawy religijnej wobec sposobu odżywiania się innych (typ postawy religijny zewnętrzny). Kobiety przykładają znacząco większą wagę niż mężczyźni do przestrzegania religijnych zasad związanych z jedzeniem (typ postawy wewnętrzny). Postrzeganie religijnych naka- zów związanych z jedzeniem jako norm społecznych oraz wspieranie innych w ich praktykowaniu (typ postawy zewnętrzny) pozostaje na zbliżonym poziomie u badanych kobiet i mężczyzn.

W grupie badanych studentów 327 osób $(84,5 \%)$ deklarowało wyznanie katolickie, 6 respondentów $(1,6 \%)$ reprezentowało inne wyznanie (prawosławne bądź świadkowie Jehowy), 54 (13,9\%) studentów określało się jako „neutralny światopoglądowo” lub "ateista”.

Tabela 2. Postawy żywieniowe a religijność badanych studentów - analiza różnic

\begin{tabular}{|c|c|c|c|c|c|c|c|c|c|c|c|c|}
\hline \multirow{3}{*}{ 离 } & \multicolumn{10}{|c|}{ RELIGIJNOŚĆ } & \multirow{2}{*}{\multicolumn{2}{|c|}{ Anova }} \\
\hline & \multicolumn{2}{|c|}{$\begin{array}{l}\text { Ogółem } \\
\mathrm{N}=387\end{array}$} & \multicolumn{2}{|c|}{$\begin{array}{c}\text { Praktykujący } \\
\text { N=248 }(64,1 \%)\end{array}$} & \multicolumn{2}{|c|}{$\begin{array}{c}\text { Niepraktykujący } \\
\text { N= } 85(22 \%)\end{array}$} & \multicolumn{2}{|c|}{$\begin{array}{c}\text { Neutralny } \\
\mathrm{N}=40(10,3 \%)\end{array}$} & \multicolumn{2}{|c|}{$\begin{array}{c}\text { Ateista } \\
\mathrm{N}=14(3,6 \%)\end{array}$} & & \\
\hline & M & SD & M & SD & M & SD & M & SD & M & SD & Test S & $\mathrm{p}$ \\
\hline $\begin{array}{l}\text { Religijna } \\
\text { wewnętrzna }\end{array}$ & 28,94 & 11,76 & 34,31 & 9,74 & 21,32 & 8,97 & 17,62 & 7,35 & 12,36 & 1,69 & 271,78 & $0,001 * * *$ \\
\hline $\begin{array}{l}\text { Wegetariańska } \\
\text { wewnętrzna }\end{array}$ & 32,55 & 7,32 & 31,95 & 7,32 & 32,42 & 6,72 & 35,42 & 7,68 & 35,71 & 7,63 & 3,14 & $0,033^{*}$ \\
\hline $\begin{array}{l}\text { Religijna } \\
\text { zewnętrzna }\end{array}$ & 26,94 & 10,22 & 31,38 & 8,97 & 20,76 & 7,42 & 17,25 & 5,90 & 13,64 & 2,53 & 147,48 & $0,001 * * *$ \\
\hline
\end{tabular}

${ }^{*} \mathrm{p}<0,05$; $^{*} \mathrm{p}<0,001$

Źródło: badanie własne. 
Analiza danych zawartych w tabeli 2 pozwala stwierdzić, że praktykowanie religijności w sposób istotny statystycznie różnicuje stopień nasilenia religijnych postaw żywieniowych. Najwyższe średnie wartości postawy religijnej wewnętrznej i religijnej zewnętrznej odnotowano u osób wierzących praktykujących, zaś najniższe - u ateistów. W tabeli zamieszczono również zależności postawy wegetariańskiej wewnętrznej względem religijności badanych studentów (okazały się istotne statystycznie).
Ta postawa wykazuje największe nasilenie w grupie ateistów, najmniejsze zaś w grupie praktykujących.

Płeć stanowi czynnik różnicujący sposób oceny funkcjonowania rodziny, o czym świadczy wyodrębnienie ról rodzinnych związanych z płcią w interpretacji wyników zastosowanego narzędzia (Margasiński, 2013). Punktem wyjścia dla zbadania zależności między oceną funkcjonowania rodziny a postawami żywieniowymi była analiza wyników w Skalach Oceny Rodziny studentek i studentów.

Tabela 3. Ocena funkcjonowania rodziny przez studentów kierunków nauczycielskich - analiza wyników stenowych z uwzględnieniem płci badanych

\begin{tabular}{|c|c|c|c|c|c|c|c|c|}
\hline \multirow{2}{*}{\multicolumn{2}{|c|}{ Skale Oceny Rodziny }} & \multicolumn{2}{|c|}{ Wyniki niskie } & \multicolumn{2}{|c|}{ Wyniki przeciętne } & \multicolumn{2}{|c|}{ Wyniki wysokie } & \multirow[t]{2}{*}{$\begin{array}{c}\text { Chi kwadrat } \\
\text { Pearsona }\end{array}$} \\
\hline & & n & $\%$ & $\mathbf{N}$ & $\%$ & $\mathbf{N}$ & $\%$ & \\
\hline \multirow{3}{*}{$\begin{array}{l}\text { Zrównoważona } \\
\text { spójność }\end{array}$} & $\begin{array}{l}\text { Kobiety } \\
\text { N=271 }\end{array}$ & 33 & 12,2 & 186 & 68,6 & 52 & 19,2 & \multirow{3}{*}{$\begin{array}{l}\chi^{2}=2,587 \\
p=0,274 \text { (n.i.) }\end{array}$} \\
\hline & $\begin{array}{l}\text { Mężczyźni } \\
\text { N=116 }\end{array}$ & 21 & 18,1 & 72 & 62,1 & 23 & 19,8 & \\
\hline & $\begin{array}{l}\text { Ogółem } \\
\mathrm{N}=387\end{array}$ & 54 & 14,0 & 258 & 66,7 & 75 & 19,4 & \\
\hline \multirow{3}{*}{$\begin{array}{l}\text { Zrównoważona } \\
\text { elastyczność }\end{array}$} & $\begin{array}{l}\text { Kobiety } \\
\text { N=271 }\end{array}$ & 20 & 7,4 & 190 & 70,1 & 61 & 22,5 & \multirow{3}{*}{$\begin{array}{l}\chi^{2}=12,969 \\
p<0,01\end{array}$} \\
\hline & $\begin{array}{l}\text { Mężczyźni } \\
\mathrm{N}=116\end{array}$ & 23 & 19,8 & 68 & 58,6 & 25 & 21,6 & \\
\hline & $\begin{array}{l}\text { Ogółem } \\
\text { N=387 }\end{array}$ & 43 & 11,1 & 258 & 66,7 & 86 & 22,2 & \\
\hline \multirow{3}{*}{ Niezwiązanie } & $\begin{array}{l}\text { Kobiety } \\
\text { N=271 }\end{array}$ & 7 & 2,6 & 178 & 65,7 & 86 & 31,7 & \multirow{3}{*}{$\begin{array}{l}\chi^{2}=2,300 \\
p=0,317 \text { (n.i.) }\end{array}$} \\
\hline & $\begin{array}{l}\text { Mężczyźni } \\
\text { N=116 }\end{array}$ & 3 & 2,6 & 67 & 57,8 & 46 & 39,7 & \\
\hline & $\begin{array}{l}\text { Ogółem } \\
\text { N=387 }\end{array}$ & 10 & 2,6 & 245 & 63,3 & 132 & 34,1 & \\
\hline \multirow{3}{*}{ Splątanie } & $\begin{array}{l}\text { Kobiety } \\
\text { N=271 }\end{array}$ & 51 & 18,8 & 178 & 65,7 & 42 & 15,5 & \multirow{3}{*}{$\begin{array}{l}\chi^{2}=16,949 \\
p<0,001\end{array}$} \\
\hline & $\begin{array}{l}\text { Mężczyźni } \\
\text { N=116 }\end{array}$ & 4 & 3,4 & 85 & 73,3 & 27 & 23,3 & \\
\hline & $\begin{array}{l}\text { Ogółem } \\
N=387\end{array}$ & 55 & 14,2 & 263 & 68,0 & 69 & 17,8 & \\
\hline \multirow{3}{*}{ Sztywność } & $\begin{array}{l}\text { Kobiety } \\
\text { N=271 }\end{array}$ & 30 & 11,1 & 194 & 71,6 & 47 & 17,3 & \multirow{3}{*}{$\begin{array}{l}\chi^{2}=6,507 \\
p<0,05\end{array}$} \\
\hline & $\begin{array}{l}\text { Mężczyźni } \\
\text { N=116 }\end{array}$ & 4 & 3,4 & 94 & 81,0 & 18 & 15,5 & \\
\hline & $\begin{array}{l}\text { Ogółem } \\
\text { N=387 }\end{array}$ & 34 & 8,8 & 288 & 74,4 & 65 & 16,8 & \\
\hline \multirow{3}{*}{ Chaotyczność } & \begin{tabular}{|l|} 
Kobiety \\
N=271
\end{tabular} & 16 & 5,9 & 150 & 55,4 & 105 & 38,7 & \multirow{3}{*}{$\begin{array}{l}\chi^{2}=2,300 \\
p=0,317 \text { (n.i.) }\end{array}$} \\
\hline & $\begin{array}{l}\text { Mężczyźni } \\
\text { N=116 }\end{array}$ & 15 & 12,9 & 70 & 60,3 & 31 & 26,7 & \\
\hline & $\begin{array}{l}\text { Ogółem } \\
\text { N=387 }\end{array}$ & 31 & 8,0 & 220 & 56,8 & 136 & 35,1 & \\
\hline \multirow{3}{*}{ Komunikacja } & $\begin{array}{l}\text { Kobiety } \\
\text { N=271 }\end{array}$ & 45 & 16,6 & 155 & 57,2 & 71 & 26,2 & \multirow{3}{*}{$\begin{array}{l}\chi^{2}=3,631 \\
p=0,163 \text { (n.i.) }\end{array}$} \\
\hline & $\begin{array}{l}\text { Mężczyźni } \\
\text { N=116 }\end{array}$ & 22 & 19,0 & 74 & 63,8 & 20 & 17,2 & \\
\hline & \begin{tabular}{|l|l|} 
Ogółem \\
N=387
\end{tabular} & 67 & 17,3 & 229 & 59,2 & 91 & 23,5 & \\
\hline \multirow{3}{*}{ Zadowolenie } & $\begin{array}{l}\text { Kobiety } \\
\mathrm{N}=271\end{array}$ & 38 & 14,0 & 102 & 37,6 & 131 & 48,3 & \multirow{3}{*}{$\begin{array}{l}\chi^{2}=25,680 \\
p<0,001\end{array}$} \\
\hline & $\begin{array}{l}\text { Mężczyźni } \\
\mathrm{N}=116\end{array}$ & 16 & 13,8 & 74 & 63,8 & 26 & 22,4 & \\
\hline & Ogółem N=387 & 54 & 14,0 & 176 & 45,5 & 157 & 40,6 & \\
\hline
\end{tabular}

Źródło: badania własne. 
Zróżnicowanie oceny funkcjonowania rodziny między grupami badanych mężczyzn i kobiet okazało się istotne statystycznie w podskalach zrównoważona elastyczność, splątanie sztywność oraz komunikacja i zadowolenie z życia rodzinnego. Biorąc pod uwagę fakt, że wymiar elastyczności zakłada kontinuum sztywność - zrównoważona elastyczność- chaotyczność, gdzie skrajne obszary świadczą o niezrównoważeniu, warto te trzy skale analizować łącznie (Margasiński, 2013). Badane kobiety znacząco częściej opowiadają się za zrównoważoną elastycznością relacji rodzinnych (większy odsetek wyników wysokich i przeciętnych), a mężczyźni za sztywnością, stąd wniosek, że zdrowsze relacje ro- dzinne w tym wymiarze występowały w ocenie kobiet. W wymiarze spójności, istotne statystycznie różnice między kobietami i mężczyznami dotyczyły świadczącej o niezrównoważeniu skali splątanie. Pod tym względem bardziej zaburzone wydają się relacje rodzinne $w$ ocenie badanych mężczyzn. Również w skalach komunikacji oraz zadowolenia z rodziny lepiej oceniają swoje rodziny kobiety.

Dla zbadania, które z czynników oceny funkcjonowania rodziny stanowia uwarunkowania religijnych postaw żywieniowych przeprowadzono analizę korelacyjną. Wybór nieparametrycznego testu Tau b Kendalla uzasadniony jest brakiem rozkładu normalnego.

Tabela 4. Religijne postawy żywieniowe a ocena funkcjonowania rodziny badanych studentów - analiza korelacyjna

\begin{tabular}{|c|c|c|c|c|c|c|c|c|c|c|c|c|}
\hline \multirow{3}{*}{$\begin{array}{l}\text { Skale Oceny } \\
\text { Rodziny }\end{array}$} & \multicolumn{4}{|c|}{$\begin{array}{c}\text { Kobiety } \\
\mathrm{N}=271\end{array}$} & \multicolumn{4}{|c|}{$\begin{array}{l}\text { Mężczyźni } \\
\text { N=116 }\end{array}$} & \multicolumn{4}{|c|}{$\begin{array}{c}\text { Ogółem } \\
\text { N=387 }\end{array}$} \\
\hline & \multicolumn{2}{|c|}{ W2 } & \multicolumn{2}{|c|}{$\mathbf{Z 2}$} & \multicolumn{2}{|c|}{ W2 } & \multicolumn{2}{|c|}{$\mathbf{Z 2}$} & \multicolumn{2}{|c|}{ W2 } & \multicolumn{2}{|c|}{$\mathbf{Z 2}$} \\
\hline & Tau & $\mathbf{P}$ & Tau & $\mathbf{P}$ & Tau & $\mathbf{P}$ & Tau & $\mathbf{P}$ & Tau & $\mathbf{P}$ & Tau & p \\
\hline $\begin{array}{l}\text { Zrównoważona } \\
\text { spójność }\end{array}$ & 0,05 & 0,301 & 0,07 & 0,138 & $0,15^{*}$ & 0,027 & $0,17^{*}$ & 0,011 & $0,09 *$ & 0,013 & $0,10^{* *}$ & 0,009 \\
\hline $\begin{array}{l}\text { Zrównoważona } \\
\text { elastyczność }\end{array}$ & 0,08 & 0,067 & 0,08 & 0,073 & $0,14 *$ & 0,042 & $0,18^{* *}$ & 0,01 & $0,11^{* *}$ & 0,004 & $0,10^{* *}$ & 0,005 \\
\hline Niezwiązanie & $-0,07$ & 0,098 & $-0,06$ & 0,148 & $-0,06$ & 0,404 & $-0,05$ & 0,447 & $-0,07$ & 0,054 & $-0,06$ & 0,105 \\
\hline Splątanie & 0,06 & 0,2 & $0,10^{*}$ & 0,024 & 0,04 & 0,567 & 0,09 & 0,169 & 0,04 & 0,331 & $0,09 *$ & 0,012 \\
\hline Sztywność & 0,05 & 0,31 & 0,07 & 0,127 & 0,00 & 0,986 & 0,08 & 0,288 & 0,02 & 0,639 & 0,06 & 0,087 \\
\hline Chaotyczność & $-0,05$ & 0,296 & $-0,01$ & 0,814 & 0,02 & 0,77 & 0,05 & 0,474 & $-0,02$ & 0,597 & 0,01 & 0,791 \\
\hline Komunikacja & 0,02 & 0,705 & 0,02 & 0,675 & 0,07 & 0,316 & 0,09 & 0,176 & 0,03 & 0,346 & 0,04 & 0,325 \\
\hline Zadowolenie & $-0,01$ & 0,796 & $-0,02$ & 0,711 & 0,10 & 0,145 & 0,11 & 0,106 & 0,03 & 0,445 & 0,01 & 0,729 \\
\hline Wskaźnik spójności & 0,03 & 0,438 & 0,03 & 0,427 & 0,10 & 0,112 & 0,11 & 0,099 & 0,07 & 0,062 & 0,05 & 0,126 \\
\hline $\begin{array}{l}\text { Wskaźnik } \\
\text { elastyczności }\end{array}$ & 0,07 & 0,086 & 0,05 & 0,259 & 0,11 & 0,089 & 0,12 & 0,196 & $0,09 * *$ & 0,01 & 0,06 & 0,076 \\
\hline Wskaźnik ogólny & 0,06 & 0,182 & 0,05 & 0,264 & $0,13 *$ & 0,045 & $0,13^{*}$ & 0,049 & $0,09 *$ & 0,012 & $0,07 *$ & 0,047 \\
\hline
\end{tabular}

* $\mathrm{p}<0,05 ;{ }^{* *} \mathrm{p}<0,01$

Źródło: badanie własne.

Analiza danych zawartych $w$ tabeli 4 pozwala dostrzec zależność między religijnymi postawami żywieniowymi a zrównoważoną spójnością i elastycznością relacji rodzinnych oraz ogólnym wskaźnikiem oceny rodziny. Zależność ta jest istotna statystycznie tylko w grupie mężczyzn. Występuje również istotna statystycznie korelacja między splątaniem relacji rodzinnych a religijną postawą zewnętrzną - ta jednak dotyczy tylko kobiet. Uzyskane wyniki pozwalają zauważyć, że relacja międzyreligijnymi postawami żywieniowymi, a oceną funkcjonowania rodziny w grupie badanych studentów modyfikowane są przez płeć jako zmienną pośredniczącą. W grupie mężczyzn prawidłowe relacje rodzinne stanowia czynnik sprzyjający przestrzeganiu religijnych zasad związanych z jedzeniem (np. okresowy post, umiar w konsumpcji żywności)oraz wspieraniu innych $\mathrm{w}$ takiej postawie. W przypadku badanych kobiet brak jest istotnych statystycznie zależności między pozytywną oceną własnej rodziny a religijnymi postawami żywieniowymi. Splątanie relacji rodzinnych, traktowane jako niezdrowe, niezrównoważone powiązania między członkami rodziny stanowi czynnik warunkujący postawę żywieniową, która wyraża się we wspieraniu innych w przestrzeganiu religijnych zasad związanych z jedzeniem.

\section{Dyskusja}

Pomimo deklaracji wiary, wielu Polaków nie przywiązuje większej wagi do praktyk religijnych, jak codzienna modlitwa, uczestnictwo w niedzielnej i świątecznej mszy świętej, czy przestrzeganie piątkowego postu (Mariański, 2011; Boguszewski, 2012).

Z przeprowadzonych badań wynika, że postawy żywieniowe oparte na religijności w większym stopniu przejawiają badane kobiety, niż mężczyźni, przy czym różnice istotne statystycznie dotyczą jedynie postaw wewnętrznych. Trudno te dane odnieść do rezultatów innych badaczy, gdyż w badaniach dotyczących religijności Polaków rzadko diagnozowane są praktyki religijne związane $\mathrm{z}$ jedzeniem (przestrzeganiem postu, etyką umiaru). Z badań CBOS 
prowadzonych w 2002 roku wynika jedynie, że 38\% Polaków nie je mięsa w piątki w Wielkim Poście (O tradycjach..., 2002). Według innego raportu CBOS kobiety częściej postrzegają wiarę religijną jako wartość nadającą sens życiu (Wiara i religijność.... 2009) Nie można jednak jednoznacznie stwierdzić, że kobiety są bardziej religijne od mężczyzn (Walesa, 2014). Badania jakościowe prowadzone wśród studentów wykazały, że młodzi ludzie przeżywają swoją religijność w sposób indywidualny, opisując praktyki religijne nie zwracają uwagi na post i umiar w jedzeniu (Różański, 2015).

Wskaźniki oceny funkcjonowania rodziny istotnie wyższe są u badanych kobiet niż mężczyzn. Warto podkreślić, że opierają się one na subiektywnych ocenach respondentów, co sugeruje, że mężczyźni są bardziej krytyczni wobec członków rodzin pochodzenia. Statystycznie wyższe oceny rodziny, a także wyższe wartości postaw religijnych wobec jedzenia w przypadku kobiet można interpretować w kategoriach większego szacunku do tradycyjnych wartości.

$\mathrm{Na}$ uwagę zasługuje ujemna statystycznie istotna zależność postawy wegetariańskiej z religijnością. Wraz ze wzrostem religijności maleje pozytywny stosunek do diet wegetariańskich, motywowany szacunkiem dla zwierząt. Warto podkreślić związek postawy wegetariańskiej z religijną odwołując się do nauczania Kościoła. Chrześcijanie nazywają wegetarianizm „ekoreligią” lub „parareligią”. Opozycyjna relacja przedstawicieli obydwu orientacji światopoglądowych jest jednak zdecydowanym uproszczeniem. Ekologiczne podejście nie jest obce nauczaniu Kościoła Katolickiego, czego dowodem jest postać świętego Franciszka z Asyżu (Zwoliński, 1996).

Analiza zależności między oceną funkcjonowania rodziny a postawami żywieniowymi opartymi na religijności wykazała, że prawidłowe relacje rodzinne jedynie w percepcji badanych mężczyzn sprzyjają pozytywnemu nastawieniu do praktyk religijnych związanych z jedzeniem. Wyniki te wydają się szczególnie interesujące w sytuacji, gdy to właśnie u mężczyzn odnotowano niższe wskaźniki oceny rodziny oraz mniejsze nasilenie postaw żywieniowych związanych z religijnością. Prawdopodobnie badani mężczyźni szacunek do żywieniowych praktyk religijnych wynoszą z domu.

W literaturze religijne praktyki związane z jedzeniem badane były przede wszystkim z punktu widzenia skutków zdrowotnych. Ich związek z uwarunkowaniami rodzinnymi może być jedynie analizowany na płaszczyźnie wspólnych posiłków. Spotkania przy rodzinnym stole sprzyjają budowaniu dobrych relacji rodzinnych, często sa związane $\mathrm{z}$ tradycyjnie przeżywanymi świętami religijnymi. Rodzinne posiłki kształtują prawidłowe nawyki żywieniowe, a jednoczesne przestrzeganie zasad umiaru związanych z religijnością dodatkowo sprzyja zdrowiu (Delormier, Frohnlich, Potvin, 2009; Dell, Josephson, 2007).

Przemiany społeczno-kulturowe, związane m.in. z laicyzacją polskiego społeczeństwa, nie znajdują odzwierciedlenia w deklaracjach badanych studentów. Ponad $86 \%$ to osoby wierzące $(64 \%$ jest zaangażowanych w praktyki religijne, 22\% - niepraktykujących).

\section{Wnioski}

Otrzymane wyniki uprawniają do wniosku, że deklarowany poziom religijności różnicuje natężenie postaw żywieniowych związanych z wyznawanym światopoglądem. Konsekwencją praktykowania religijności są religijne postawy wobec jedzenia, związane $\mathrm{z}$ przestrzeganiem postu, etyką umiaru, celebrowaniem wspólnych posiłków, szacunkiem do jedzenia. Chociaż takie postawy wynikają z przyjętego światopoglądu, a nie motywacji zdrowotnej, wydają się korzystne z punktu widzenia zdrowia.

Rodzina może mieć istotne znaczenie dla kształtowania postaw żywieniowych opartych na religijności, niemniej dotyczy to jedynie mężczyzn. Można również wnioskować o interakcji między oceną rodziny pochodzenia a płcią oraz jej roli w ustaleniu natężenia analizowanych tutaj postaw. Niemniej jednak przypuszczenie to należy zweryfikować w kolejnych badaniach empirycznych.

\section{Literatura:}

1. Babicz-Zielińska, E., Zabrocki, R. (2007). Postawy konsumentów wobec prozdrowotnej wartości żywności. Żywność. Nauka. Technologia. Jakość, 6(55), 81-89.

2. Baxter, H. (2001). Nibbles. Religion and Eating Disorder. European Eating Disorders Review, 9(2), 137-139.

3. Boguszewski, R. (2012). Zmiany w zakresie wiary i religijności Polaków po śmierci Jana Pawła II. Warszawa: COBOS.

4. Borowiec, A., Lignowska, I. (2012). Czy ideologia healthismu jest cechą dystynktywną klasy średniej w Polsce? Kultura i Społeczeństwo, 2, 95-111.

5. Buczak, A. (2017). Szacunek jako element postawy wobec odżywiania - w poszukiwaniu sprawności moralnych w edukacji żywieniowej, W: I. Jazukiewicz, E. Rojewska, Sprawności moralne a przestrzenie pedagogiczne, Rozprawy i Studia t. 954 (s. 269-283). Szczecin: Wydawnictwo Uniwersytetu Szczecińskiego.

6. Collins, C., Duncanson, K., Burrows, T. (2014). A systematic review investigating associations between parenting style and child feeding behaviours. Journal of Human Nutrition Dietetics 7(6), 557-568. D0I: 10.1111/jhn.12192.

7. Czarnocińska, J., Jeżewska-Zychowicz, M., Babicz-Zielińska, E., Kowalkowska, J., Wądołowska, L. (2013). Postawy względem żywności, żywienia i zdrowia a zachowania żywieniowe dziewcząt $i$ młodych kobiet w Polsce. Olsztyn: Wydawnictwo Uniwersytetu Warmińsko-Mazurskiego. 
8. Dell, M.L., Josephson, A.M. (2007). Religious and spiritual factors in childhood and adolescent eating disorder and obesity. Souther Medical Associacion 100(6), 628-632. D0I:10.1097/SMJ.0b013e31805fe689.

9. Delormier, T., Frohnlich, K.L., Potvin, L. (2009). Food and eating as social practice - understanding eating patterns as social phenomena and implications for public health. Sociology of Health \&Illness 31(2), 215228. DOI: 10.1111/j.1467-9566.2008.01128.x.

10. Demel, M. (2002). Pedagogika zdrowia. Chowanna, 1(18), 13-26.

11. Fox, R. (2003). Food and eating: an anthropological perspective. Social Issues Research Center, Oxford. Pobrane z: www.sirc.org/publik/foxfood.pdf .

12. Fulkerson, J.A., Neumark-Sztainer, D., Story, M., (2006). Adolescent and parent views of family meals. Journal of American Dietetic Associacion, 106, 526-532. DOI: 10.1016/j.jada.2006.01.006

13. Gawęcki, J. (2010). Żywienie człowieka. Podstawy nauki o żywieniu, T.1. Warszawa: Wydawnictwo Naukowe PWN.

14. Holubcikova, J., Kolarcik, P., Madarasova Geckova, A., van Dijk, J.P., Reijneveld, S.A., (2016). Lack of parental rule-setting on eating is associated with a wide range of adolescent unhealthy eating behaviour both for boys and girls. BMC Public Health 16:359. DOI: 10.1186/s12889-016-3002-4.

15. Hossain, M.Z. (2014). What does Islam say about dieting? Journal of Religion and Health, 53, 1003-1012. DOI: $10.1007 / s 10943-013-9698-x$.

16. Houldcroft, L., Haycraft, E., Farrow, C. (2014). Peer and friend influences on children's eating. Social Development, 23(1), 19-40. DOI: 10.1111/sode.12036.

17. Jeżewska-Zychowicz, M. (2007). Zachowania żywieniowe i ich uwarunkowania. Warszawa: Wydawnictwo SGGW.

18. Kim, K.H. (2007). Religion, weight perception, and weight control behaviour. Eating Behaviours, 8, 121131. DOI:10.1016/j.eatbeh.2006.03.001.

19. Konturek, S. (2013). Fizjologia człowieka. Podręcznik dla studentów medycyny. Wrocław: Wydawnictwo Edra Urban \& Partner.

20. Kozirok, W. (2015). Reklama żywności - postawy i zachowania konsumentów. Zeszyty Naukowe Uniwersytetu Szczecińskiego, 866(39), 45-54.

21. Kucharska, A., Sińska, B., Marszałek, K., Michota-Katulska, E., Zegan, M. (2015). Wybrane elementy stylu życia wyznawców adwentyzmu i katolicyzmu. Pielęgniarstwo Polskie 1(55), 28-32.

22. Leszczyński, B. (2014). Znaczenie i symbolika postu. Studia Koszalińsko-Kołobrzeskie, 21, $135-145$.

23. Maison, D. (2013). Motywy i bariery zmiany postaw i zachowań żywieniowych. Żywienie Człowieka i Metabolizm, 3, 192-212.

24. Margasiński, A. (2013). Skale Oceny Rodziny. Polska adaptacja FACES IV-Flexibility and Cohesion Evaluation Scales Davida H. Olsona. Warszawa: Pracownia Testów Psychologicznych.

25. Margasiński, A. (2006). Rodzina w Modelu Kołowym i FACES IV Davida H. Olsona. Nowiny Psychologiczne 4, 69-87.

26. Mariański, J. (2011). Katolicyzm polski, ciagłość i zmiana - studium socjologiczne. Kraków: WAM.

27. Morris, K.D.V., Parra, G.R., Stender, S.R.S. (2011). Eating Attitudes and Behaviors Among Female College Students. Journal of College Counseling, 14(1), 21-33. DOI: 10.1002/j.2161-1882.2011.tb00061.x.

28. Narojek, L. (1993). Niektóre aspekty uwarunkowań zachowań żywieniowych. Warszawa: Wydawnictwo SGGW.

29. Nastaskin, R.S., Fiocco, A.J. (2015). A survey of diet self-efficacy and food intake in students with high and low perceived stress, Nutrition Journal 14:42. Pobrane z: www.ncbi.nlm.nih.gov/pmc/articles/ PMC4416420/.DOI:10.1186/s12937-015-0026-z.

30. O tradycjach wielkopostnych i nieświętym świętowaniu (2002). Warszawa: CBOS.

31. Ogińska-Bulik, N., Juczyński, Z. (2008). Osobowość - stres a zdrowie. Warszawa: Wydawnictwo Diffin.

32. Olson, D.H. (2013). Kwestionariusz FACES IV i Model Kołowy. Badanie walidacyjne. Warszawa: Pracownia Testów Psychologicznych.

33. Rawlings, E. (2009). Choosing Health? Exploring Children`s Eating Practices at Home and at School. Antipode, 41(5), 1085-1108.

34. Różański, T. (2015). Oblicza religijności młodzieży studenckiej - analiza wybranych komponentów. Pedagogia Christiana, 1(35), 295-309.

35. Smith, M.H., Richards, P.S., Maglio, Ch.J. (2004). Examining the relationship between religious orientation and eating disturbances, Eating Behaviours, 5, 171-180. DOI: 10.1016/S1471-0153(03)00064-3.

36. Stalmach, M. (2015). Kontekst społeczny zdrowia i zachowań zdrowotnych. Posiłki rodzinne. W: J. Mazur (red.), Zdrowie i zachowania zdrowotne młodzieży szkolnej w Polsce na tle wybranych uwarunkowań socjodemograficznych. Wyniki badań HBSC 2014 (s. 44-51). Warszawa: Instytut Matki i Dziecka.

37. Steeves, E.A., Jones-Smith, J., Hopkins, L., Gittelsohn, J. (2016). Perceived social support from friends and parents for eating behavior and diet quality among low-income urban minority youth. Journal of Nutrition Education and Behaviour, 48(5), 304-310. DOI: 10.1016/j.jneb.2015.12.014. 
38. Tabak, I. (2015). Kontekst społeczny zdrowia i zachowań zdrowotnych. Jakość komunikacji z rodzicami. W: J. Mazur (red.), Zdrowie i zachowania zdrowotne młodzieży szkolnej w Polsce na tle wybranych uwarunkowań socjodemograficznych. Wyniki badań HBSC 2014 (s. 32-37). Warszawa: Instytut Matki i Dziecka.

39. Walesa, Cz. (2014). Różnice w zakresie religijności kobiet i mężczyzn. Horyzonty Psychologii, 4, 45-66.

40. Whitehead, D. (2004). Health promotion and health education: advancing the concepts. Journal of Advanced Nursing, 47(3), 311-320. DOI: 10.1111/j.1365-2648.2004.03095.x.

41. Wiara i religijność Polaków dwadzieścia lat po rozpoczęciu przemian ustrojowych. Komunikat z badań (2009). Warszawa: CBOS.

42. Wojciszke, B. (2002). Człowiek wśród ludzi. Zarys psychologii społecznej. Warszawa: Wydawnictwo Naukowe SCHOLAR.

43. Woźniak, B. (2013). Regulacyjna funkcja religii a sposób odżywiania się i zdrowie osób zaangażowanych religijnie. W: B. Tobiasz-Adamczyk (red.), Od socjologii medycyny do socjologii żywienia. (Część II. Wybrane aspekty socjologii żywienia) (s. 129-146). Kraków: Wydawnictwo Uniwersytetu Jagiellońskiego.

44. Ziółkowska, B. (2014). Psychospołeczne aspekty nienormatywnej masy ciała. Poznań: Wydawnictwo Naukowe UAM.

45. Zwoliński, A. (1996). Wegetarianizm - rozmowy przy stole. Kraków: Wydawnictwo „Gotów”.

46. Zwoliński, A. (2006). Jedzenie w relacjach społecznych. Kraków: Wydawnictwo Naukowe Papieskiej Akademii Teologicznej.

47. Zwoliński, A. (2008). Wychowanie do umiaru. Pedagogika Katolicka, 2(1), 57-70. 